\title{
Pengaruh Penggunaan Tepung Kulit Pisang Kepok Fermentasi (Musa paradisiaca normalis) terhadap Performan Ayam Broiler
}

\author{
(Effect of Administration of Fermented Banana Peel as Partial Substitution \\ of Commercial Finisher Diets on Broiler Performances)
}

\author{
Yeyen Safitri ${ }^{1}$, Zulfan ${ }^{1}$, Herawati Latif ${ }^{1}$ \\ ${ }^{1}$ Program Studi Peternakan, Fakultas Pertanian, Universitas Syiah Kuala
}

\begin{abstract}
Abstrak: Tujuan penelitian ini adalah untuk mengetahui pengaruh substitusi sebagian ransum komersil periode finisher dengan tepung kulit pisang kepok (Musa paradisiaca normalis) fermentasi + bungkil kelapa + feed supplement terhadap performan ayam broiler. Penelitian dilakukan di Laboratorium Lapangan Peternakan (LLP), Program Studi Perternakan, Fakultas Pertanian, Universitas Syiah Kuala. Penelitian menggunakan 100 ekor anak ayam broiler (DOC) strain Lohmann. Perlakuan yang dicobakan adalah pemberian tepung kulit pisang kepok fermentasi + bungkil kelapa + feed supplement, sebanyak $0 \%\left(\mathrm{P}_{1}\right), 2,5 \%+1,5 \%+1 \%\left(\mathrm{P}_{2}\right)$, $5 \%+3 \%+1 \%\left(\mathrm{P}_{3}\right) .7,5 \%+4,5 \%+1 \%\left(\mathrm{P}_{4}\right)$, dan $10 \%+6 \%+1 \%\left(\mathrm{P}_{5}\right)$ Parameter yang diamati meliputi berat badan akhir, pertambahan berat badan, konsumsi ransum, dan konversi ransum. Hasil penelitian memperlihatkan bahwa substitusi ransum komersil dengan sebanyak-banyaknya $10 \%$ tepung kulit pisang kepok fermentasi $+6 \%$ bungkil kelapa $+1 \%$ feed supplement tidak berpengaruh nyata $(\mathrm{P}>0.05)$ terhadap berat badan akhir, pertambahan berat badan, konsumsi ransum, dan konversi ransum ayam broiler.
\end{abstract}

Kata Kunci: broiler, performan, kulit pisang, fermentasi

\begin{abstract}
The aim of present study was to determine effect of partial substitution of commercial broiler finisher diet with a fermented banana (Musa paradisiaca normalis) peel + coconut meal + feed supplement to performances of broiler chickens. The study was conducted in Field Laboratory, Department of Animal Husbandry, Faculty of Agriculture, Syiah Kuala University. As many as 100 chicks, strain lohmann, were used in this study. The treatment was the provision of fermented banana peel + coconut meal + feed supplement, with the level of $0 \%\left(\mathrm{P}_{1}\right)$, $2,5 \%+1,5 \%+1 \%\left(\mathrm{P}_{2}\right), 5 \%+3 \%+1 \%\left(\mathrm{P}_{3}\right) .7,5 \%+4,5 \%+1 \%\left(\mathrm{P}_{4}\right)$, and $10 \%+6 \%+1 \%\left(\mathrm{P}_{5}\right)$, respectively. The parameters observed were final body weight, average body weight gain, feed consumption, and feed conversion. Results of study showed that administration of fermented banana peel up to $10 \%+$ coconut meal $6 \%+$ feed supplement $1 \%$ as partial substitution of commercial finisher broiler diet was not significant effect $(\mathrm{P}>0.05)$ on final body weight, average body weight gain, feed consumption, and feed conversion of broiler chickens
\end{abstract}

Key words: broiler, performance, fermentation, banana peel

\section{PENDAHULUAN}

Ayam broiler merupakan salah satu jenis ternak yang dapat dipilih dalam upaya meningkatkan ketersediaan protein hewani. Kendala utama dalam pemeliharaan ayam broiler terutama bagi peternak skala menengah ke bawah adalah biaya pakan yang tinggi yang dapat mencapai 65-70\% dari total biaya produksi. Oleh karena itu diperlukan upaya mencari bahan pakan alternatif yang mudah didapat, tidak bersaing dengan manusia, dan harga yang relatif murah tanpa mengabaikan nilai gizinya. Salah satu bahan tersebut adalah kulit pisang kepok.

Kulit pisang merupakan bagian terluar dari buah pisang yang tidak dikonsumsi oleh manusia. Umumnya, kulit pisang dibuang begitu saja atau digunakan untuk makanan kambing dan sapi. Kulit pisang sangat jarang digunakan untuk makanan ayam karena memiliki tekstur kasar dan kandungan serat kasar tinggi. Meskipun demikian, kulit pisang ini masih memungkinkan diberikan pada unggas dalam jumlah terbatas setelah mengalami proses pengolahan terlebih dahulu (Udjianto, 2003). Hasil penelitian Udjianto et al. (2005) memperlihatkan penambahan kulit pisang fermentasi dapat dilakukan hingga 5\% dalam ransum komersial ayam broiler. Koni (2012) melaporkan campuran kulit pisang dan ampas kelapa dengan perbandingan 2:1 dapat digunakan hingga 15\% pengganti jagung dalam 
ransum ayam buras. Hasil penelitian Anggriawan et al. (2013) memperlihatkan tepung kulit pisang raja bulu (Musa paradisiaca L. var sapientum) dapat digunakan 5\% selama fase finisher tanpa berpengaruh nyata terhadap berat badan dan konsumsi ransum ayam broiler. Penelitian Koni (2013) memperlihatkan bahwa penggunaan tepung kulit pisang kepok yang difermentasi maksimal 5\% tidak nyata menurunkan berat badan ayam broiler. Akan tetapi, jika pakan tersebut digunakan $10 \%$ atau lebih menurunkan berat badan ayam tersebut secara nyata. Salah satu pembatas penggunaan tepung kulit pisang ini adalah kandungan protein yang rendah dan serat kasar yang tinggi (Koni, 2009).

Berdasarkan permasalahan tersebut, penggunaan tepung kulit pisang perlu dicampur dengan bahan pakan lain misalnya bungkil kelapa. Bungkil kelapa merupakan limbah dari pabrik minyak kelapa. Bungkil kelapa cukup banyak tersedia di Aceh dan harganya pun relatif murah. Meskipun tidak setinggi pada bungkil kedele, kandungan protein pada bungkil kelapa masih cukup tinggi (sekitar 21\%) dan hampir sama dengan kandungan protein dalam ransum komersil (Wahyu, 1992).

Zat-zat gizi lainnya terutama vitamin, mineral, dan asam amino di dalam ransum substitusi perlu dilengkapi dengan penambahan feed supplement. Feed supplement merupakan bahan makanan berupa campuran preparat vitamin, mineral, dan antibiotika guna melengkapi ransum. Tujuan penelitian ini adalah untuk mengetahui pengaruh pemberian tepung kulit pisang kepok (Musa paradisiaca normalis) fermentasi + bungkil kelapa + feed supplement sebagai substitusi sebagian ransum komersil periode finisher terhadap performan ayam broiler.

\section{Tempat dan Waktu}

\section{MATERI DAN METODE}

Penelitian ini dilakukan di Laboratorium Lapangan Peternakan (LLP), Program Studi Peternakan, Fakultas Pertanian, Univeritas Syiah Kuala, Banda Aceh tanggal 1 April sampai dengan 5 Mei 2016.

\section{Materi Penelitian}

Penelitian ini menggunakan sebanyak 100 ekor Day Old Chick (DOC) ayam broiler, strain lohmann, produksi PT. Japfa, Medan.

\section{Bahan dan Alat}

Bahan yang digunakan dalam penelitian ini terdiri dari ransum komersil broiler berupa N511 dan N512 Bravo, kulit pisang kepok, ragi tape, bungkil kelapa, vitachick, vitastress, feed supplement (top mix), vaksin ND, vaksin gumboro, desinfektan, koran bekas, litter, plastik, kantung plastik, dan kapur. Peralatan yang digunakan ini meliputi kandang individual, tempat pakan, tempat minum, lampu pemanas, timbangan, disc mill, kukusan, dan kompor.

\section{Ransum Perlakuan}

Penelitian ini menggunakan ransum dasar berupa ransum komersil yaitu N511 Bravo untuk periode starter (umur 0-3 minggu) dan N511 Bravo yang sebagian disubstitusi dengan tepung kulit pisang kepok fermentasi + bungkil kelapa + feed supplement untuk periode finisher (umur 4-5 minggu). Ransum perlakuan yang digunakan adalah sebagai berikut: 
$\mathrm{P}_{1}$ : Ransum komersil broiler 512 Bravo 100\% + tepung kulit pisang kepok fermentasi $0 \%$ + bungkil kelapa $0 \%+$ feed supplement $0 \%$ (kontrol)

$\mathrm{P}_{2}$ : Ransum komersil broiler 512 Bravo 95,0\% + tepung kulit pisang kepok fermentasi $2,5 \%$ + bungkil kelapa $1,5 \%+$ feed supplement $1 \%$

$\mathrm{P}_{3}$ : Ransum komersil broiler 512 Bravo 91,0\% + tepung kulit pisang kepok fermentasi $5,0 \%+$ bungkil kelapa 3,0\% + feed supplement $1 \%$

$\mathrm{P}_{4}$ : Ransum komersil broiler 512 Bravo 87,0\% + tepung kulit pisang kepok fermentasi $7,5 \%$ + bungkil kelapa 4,5\% + feed supplement $1 \%$

$\mathrm{P}_{5}$ : Ransum komersil broiler 512 Bravo 83,0\% + tepung kulit pisang kepok fermentasi 10,0\% + bungkil kelapa 6,0\%+feed supplement $1 \%$

Tabel 1. Susunan dan Kandungan Zat Gizi Ransum Penelitian

\begin{tabular}{|c|c|c|c|c|c|}
\hline \multirow[t]{2}{*}{ Bahan Pakan } & \multicolumn{5}{|c|}{$\begin{array}{l}\text { Ransum Komersil Broiler Disubstitusi dengan Tepung Kulit Pisang Kepok } \\
\text { Fermentasi + Bungkil Kelapa + Feed Supplement }\end{array}$} \\
\hline & $\mathrm{P}_{1}$ & $\mathrm{P}_{2}$ & $\mathrm{P}_{3}$ & $\mathrm{P}_{4}$ & $\mathrm{P}_{5}$ \\
\hline 512 Bravo*) & 100 & 95,0 & 91,0 & 87,0 & 83,0 \\
\hline \multirow{2}{*}{\multicolumn{6}{|c|}{ Kepok Fermentasi**) }} \\
\hline & & & & & \\
\hline Bungkil Kelapa ${ }^{* * * *}$ & 0 & 1,5 & 3,0 & 4,5 & 6,0 \\
\hline Feed Supplement & 0 & 1,0 & 1,0 & 1,0 & 1,0 \\
\hline Jumlah & 100 & 100 & 100 & 100 & 100 \\
\hline \multicolumn{6}{|c|}{ Kandungan Zat Gizi Berdasarkan Perhitungan } \\
\hline Protein $(\%)$ & $19,00-21,50$ & $18,97-21,34$ & $19,13-21,40$ & $19,29-21,46$ & $19,45-21,52$ \\
\hline Serat Kasar $(\%)(\max )$ & 5,00 & 5,39 & 5,85 & 6,28 & 6,73 \\
\hline Lemak Kasar (\%) (min) & 5,00 & 4,86 & 4,77 & 4,67 & 4,58 \\
\hline $\mathrm{Ca}(\%)(\min )$ & 0,90 & 1,05 & 1,20 & 1,36 & 1,52 \\
\hline $\mathrm{P}(\%)(\min )$ & 0,60 & 0,65 & 0,70 & 0,76 & 0,81 \\
\hline \multicolumn{6}{|c|}{$\begin{array}{l}\text { Kandungan zat gizi berdasarkan label kemasan PT. Charoen Pokphand: protein kasar 19,0-21,5\%, lema } \\
\text { kasar } 5 \% \text {, serat kasar } 5 \% \text {, Ca } 0,9 \% \text {, dan P } 0,6 \%\end{array}$} \\
\hline Kandungan zat gizi & Uart & & & & \\
\hline
\end{tabular}

\section{Pembuatan Tepung Kulit Pisang Fermentasi}

Proses pembuatan tepung kulit pisang fermentasi dilakukan sebagai berikut: (1) kulit pisang kepok dikumpulkan, (2) dicuci, (3) dipotong kecil-kecil dengan ukuran $\pm 5 \mathrm{~cm}$, (4) dikukus selama \pm 25 menit untuk mematikan kuman pathogen, (5) diangin-anginkan, (6) dicampur ragi sebanyak $3 \mathrm{~g} / \mathrm{kg}$ kulit pisang, (7) dibungkus di dalam kantung plastik tidak padat agar jamur dapat tumbuh optimum selama 4 hari, (8) disimpan pada suhu ruang selama 48 jam, dan (9) dikeringkan, dan (10) digiling hingga menjadi tepung.

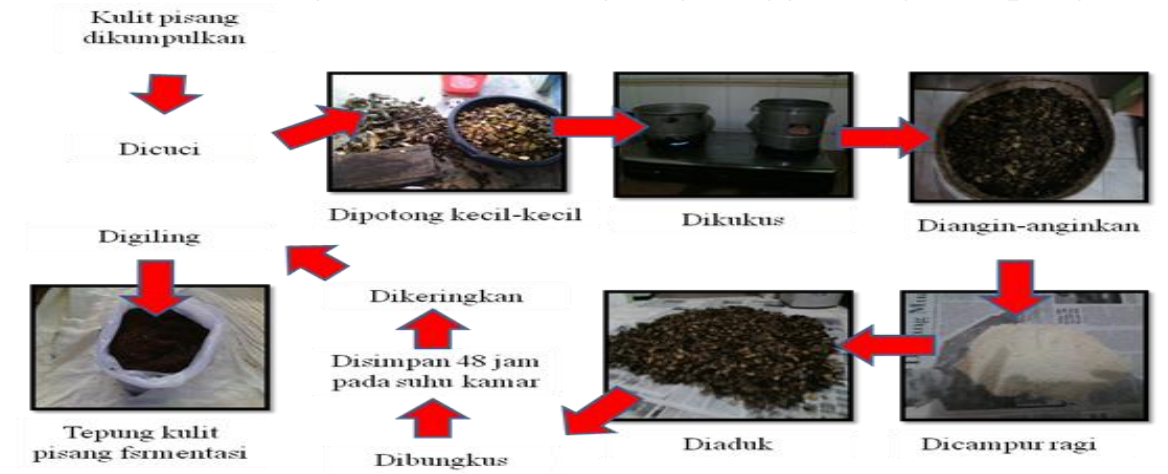

Gambar 1. Skema Proses Pembuatan Tepung Kulit Pisang Fermentasi 


\section{Rancangan Penelitian}

Rancangan penelitian yang digunakan adalah Rancangan Acak Kelompok (Randomized Block Design) terdiri dari 5 perlakuan dan 4 kelompok. Setiap kelompok merupakan unit percobaan yang terdiri dari 5 ekor ayam.

Model matematika penelitian menurut Ott (1993) adalah sebagai berikut :

$Y_{i j}=\mu+\alpha_{i}+\beta_{j}+\varepsilon_{i j}$

Keterangan:

$\mu=$ Rataan umum

$\alpha_{i}=$ Pengaruh perlakuan ke- $i$

$\beta_{j}=$ Pengaruh kelompok ke-j

$\varepsilon_{i j}=$ Pengaruh galat kelompok ke- $j$ dari perlakuan ke- $i$

\section{Pelaksanaan Penelitian}

a. Tahap persiapan; terdiri dari persiapan kandang dan ransum. Persiapan kandang meliputi pembersihan kandang, sanitasi kandang (dalam kandang dan luar kandang), pencucian, penyemprotan desinfektan, persiapan tempat pakan dan tempat minum, pemasangan bola lampu pijar, dan penomoran kandang secara acak. Persiapan ransum meliputi persiapan bahan pakan, pembuatan tepung kulit pisang kepok fermentasi, dan penyusunan ransum perlakuan.

b. Tahap pemeliharaan; terdiri dari periode starter (0-3 minggu) dan finisher (4-5 minggu). Selama periode 0-3 minggu, ayam dari semua perlakuan diberikan $100 \%$ ransum komersil $\mathrm{R}_{511}$. Selama periode 4-5 minggu, ayam dari perlakuan $\mathrm{P}_{1}$ diberikan $100 \%$ ransum komersil $R_{512}$, sedangkan perlakuan $P_{2}-P_{5}$, diberikan ransum komersil $R_{512}$ yang disubstitusi dengan tepung kulit pisang kepok fermentasi + bungkil kelapa + feed supplement sebanyak 4-17\%. Ransum diberikan ad libitum dengan pemberian dua kali sehari, yaitu pukul 08.00 dan 17.00 WIB. Vaksinasi ND dilakukan pada umur 3 hari via tetes mata dan diulangi pada umur 21 hari via suntikan intramuskuler. Vaksinasi gumboro dilakukan pada umur 12 hari via tetes mulut.

c. Tahap pengambilan data; dilakukan tiap-tiap minggu dari minggu pertama hingga minggu terakhir. Semua ayam dari tiap unit percobaan ditimbang untuk mengetahui berat badan dan pertambahan berat badan tiap-tiap minggu. Ransum sisa ditimbang setiap akhir minggu untuk mengetahui konsumsi ransum mingguannya. Konversi ransum diperoleh dari data pertambahan berat badan dan konsumsi ransum.

\section{Parameter Penelitian}

Parameter yang diamati dalam penelitian adalah performan ayam broiler selama pemeliharaan 35 hari, yang meliputi berat badan akhir, pertambahan berat badan, konsumsi ransum, dan konversi ransum.

\section{Analisis Data}

Data yang diperoleh diolah secara statistik dengan menggunakan analysis of variance (ANOVA). Jika diantara perlakuan terdapat perbedaan yang nyata $\left(\mathrm{F}_{\text {obs. }}>\mathrm{F}_{\text {tab. } \alpha=0.05}\right)$ maka dilakukan uji lanjut dengan menggunakan Uji Jarak Berganda Duncan (Ott, 1993). 


\section{HASIL DAN PEMBAHASAN}

\section{Berat Badan dan Pertambahan Berat Badan}

Berat badan dan rataan pertambahan berat ayam broiler per minggu yang diberi ransum komersil yang disubstitusi dengan tepung kulit pisang kepok fermentasi + bungkil kelapa + feed supplement selama periode finisher (4-5 minggu) diperlihatkan pada Tabel 2. Hasil sidik ragam memperlihatkan bahwa substitusi sebagian ransum komersil dengan tepung kulit pisang kepok fermentasi + bungkil kelapa + feed supplement selama periode finisher tidak berpengaruh nyata $(\mathrm{P}>0,05)$ terhadap berat badan umur 5 minggu dan ratan pertambahan berat badan (PBB) per minggu ayam broiler. Berat badan dan pertambahan berat badan ayam broiler yang diberikan ransum komersil yang disubstitusi dengan sebanyak-banyaknya $10 \%$ tepung kulit pisang kepok fermentasi $+6 \%$ bungkil kelapa $+1 \%$ feed supplement $\left(\mathrm{P}_{2}-\mathrm{P}_{5}\right)$ tidak jauh berbeda dengan berat badan dan PBB ayam broiler yang diberikan 100\% ransum komersil $\left(\mathrm{P}_{1}\right)$.

Tabel 2. Berat Badan Akhir dan Pertambahan Berat Badan Ayam Broiler yang Diberi Ransum Komersil yang Disubstitusi Tepung Kulit Pisang Kepok Fermentasi + Bungkil Kelapa + Feed Supplement selama Periode Finisher

\begin{tabular}{|c|c|c|c|c|c|}
\hline \multirow[b]{2}{*}{ Parameter } & \multicolumn{5}{|c|}{$\begin{array}{c}\text { Ransum Komersil + Tepung Kulit Pisang Kepok Fermentasi + } \\
\text { Bungkil Kelapa }+ \text { Feed Supplement }\end{array}$} \\
\hline & $\begin{array}{c}100 \% \mathrm{RK}+0 \% \\
\mathrm{TKP}+0 \% \\
\mathrm{BK}+0 \% \mathrm{FS} \\
\left(\mathrm{P}_{1}\right)\end{array}$ & $\begin{array}{c}95 \% \mathrm{RK}+2.5 \% \\
\mathrm{TKP}+1.5 \% \\
\mathrm{BK}+1 \% \mathrm{FS} \\
\left(\mathrm{P}_{2}\right) \\
\end{array}$ & $\begin{array}{c}91 \% \mathrm{RK}+5 \% \\
\mathrm{TKP}+3 \% \\
\mathrm{BK}+1 \% \mathrm{FS} \\
\left(\mathrm{P}_{3}\right) \\
\end{array}$ & $\begin{array}{c}87 \% \mathrm{RK}+7.5 \% \\
\mathrm{TKP}+4.5 \% \\
\mathrm{BK}+1 \% \mathrm{FS} \\
\left(\mathrm{P}_{4}\right) \\
\end{array}$ & $\begin{array}{c}83 \% \mathrm{RK}+10 \% \\
\mathrm{TKP}+6 \% \\
\mathrm{BK}+1 \% \mathrm{FS} \\
\left(\mathrm{P}_{5}\right)\end{array}$ \\
\hline $\begin{array}{l}\text { Berat badan akh } \\
\text { Berat badan } 5 \\
\text { minggu }\end{array}$ & al body weight) ( $\mathrm{g}$ & $1846,75 \pm 183,02$ & $1886,89 \pm 163,49$ & $1912,98 \pm 214,16$ & $1842,83 \pm 218,22$ \\
\hline \multicolumn{6}{|c|}{$\begin{array}{l}\text { Rataan pertambahan berat badan per minggu (average body weight gain) (g/ekor/minggu) } \\
\text { Finisher }\end{array}$} \\
\hline $\begin{array}{l}\text { (4-5 Minggu) } \\
\text { Broiler }\end{array}$ & $468,59 \pm 46,74$ & $437,20 \pm 42,41$ & $456,89 \pm 35,72$ & $469,56 \pm 49,19$ & $435,99 \pm 60,19$ \\
\hline$(0-5$ minggu $)$ & $370,71 \pm 39,82$ & $358,76 \pm 36,60$ & $366,79 \pm 13,48$ & $372,01 \pm 42,83$ & $357,98 \pm 43,64$ \\
\hline
\end{tabular}

Hasil ini menunjukkan bahwa tepung kulit pisang kepok fermentasi dapat mensubstitusi sampai $10 \%$ ransum komersil selama periode finisher dengan penambahan $6 \%$ bungkil kelapa dan $1 \%$ feed supplement tanpa menurunkan secara nyata bobot badan dan rataan pertambahan berat badan ayam broiler. Hasil penelitian ini sesuai dengan Koni et al. (2013), walaupun terjadi peningkatan protein kasar pada kulit pisang kepok yang difermentasi, namun penggunaannya terbatas hingga $10 \%$ dalam ransum ayam pedaging. Bila digunakan lebih dari 10\% dapat menurunkan bobot badan. Protein kasar bahan pakan hasil fermentasi sebagian terdiri dari fraksi asam nukleat yang berasal dari sel-sel mikroba, protein tersebut sulit dicerna oleh saluran pencernaan unggas sehingga ketersediaan protein untuk pertumbuhan berkurang (Budiansyah, 2010). 


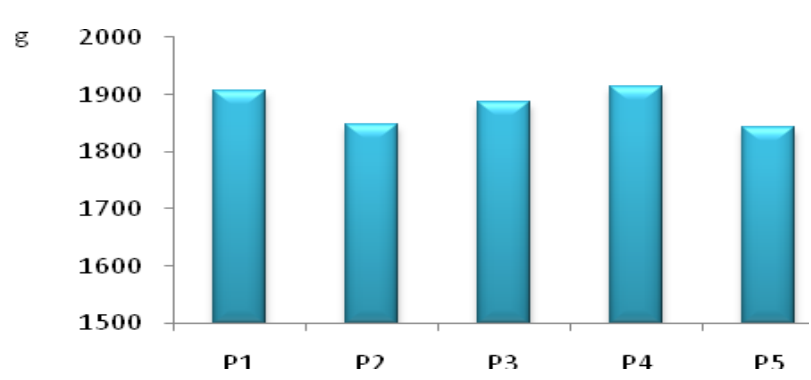

Gambar 2. Berat Badan Ayam Broiler pada Akhir Minggu ke-5 dari Semua Perlakuan

Serat kasar yang tinggi yang terkandung dalam kulit pisang akan menurunkan energi metabolis pakan, karena terjadinya penurunan kecernaan bahan, sehingga terjadi penurunan penyerapan zat-zat makanan (Bahri dan Rusdi, 2008). Tingkat energi metabolis berhubungan erat dengan kecernaan dan penyerapan zat-zat makanan. Hal ini sejalan dengan yang dilaporkan oleh McDonald et al. (1994) bahwa energi metabolisme ditentukan oleh kandungan dan keseimbangan zat makanan dalam bahan dan serat kasar merupakan faktor utama yang menentukan energi metabolisme.

\section{Konsumsi Ransum}

Rataan konsumsi ransum ayam broiler per minggu yang diberi ransum komersil yang disubstitusi dengan tepung kulit pisang kepok fermentasi + bungkil kelapa + feed supplement selama periode finisher (4-5 minggu) diperlihatkan pada Tabel 3. Hasil sidik ragam memperlihatkan bahwa pemberian ransum komersil yang sebagian disubstistusi dengan tepung kulit pisang kepok fermentasi + bungkil kelapa + feed supplement selama periode finisher (4-5 minggu) tidak berpengaruh nyata $(\mathrm{P}>0,05)$ terhadap rataan konsumsi ransum ayam broiler, baik selama periode finisher maupun selama periode pemeliharaan 0-5 minggu.

Rataan konsumsi ransum ayam broiler per minggu dari semua perlakuan tidak jauh berbeda. Hasil ini menunjukkan bahwa penggunaan tepung kulit pisang kepok fermentasi sampai $10 \%$ di dalam ransum finisher tidak menyebabkan penurunan konsumsi ransum ayam broiler. Ayam broiler yang diberikan ransum komersil dengan substitusi tepung kulit pisang kepok fermentasi sampai $10 \%$ selama periode finisher tidak memperlihatkan penolakan terhadap pakan tersebut. Tidak dapat dipastikan apakah tepung kulit pisang kepok fermentasi memiliki palatabilitas yang rendah atau tidak, kenyataannya ayam broiler tetap mengkonsumsi ransum-ransum yang disubstitusi dengan tepung kulit pisang kepok fermentasi tersebut. 
Tabel 3. Konsumsi Ransum Ayam Broiler yang Diberi Ransum Komersil yang Disubstitusi Tepung Kulit Pisang Kepok Fermentasi + Bungkil Kelapa + Feed Supplement selama Periode Finisher

\begin{tabular}{|c|c|c|c|c|c|}
\hline \multirow[t]{2}{*}{ Periode } & \multicolumn{5}{|c|}{ Ransum Komer } \\
\hline & $P_{1}$ & $\mathrm{P}_{2}$ & $\mathrm{P}_{3}$ & $\mathrm{P}_{4}$ & $P_{5}$ \\
\hline \multicolumn{6}{|l|}{ Finisher (4-5 Minggu) } \\
\hline Total Konsumsi 4-5 minggu & 2115,61 & 2067,95 & 2077,41 & 2111,94 & 2073,43 \\
\hline (g/ekor) & $\pm 197,05$ & $\pm 177,79$ & $\pm 281,48$ & $\pm 192,48$ & $\pm 316,15$ \\
\hline Rata-rata Konsumsi per minggu 4- & 1057,81 & 1033,97 & 1038,71 & 1055,97 & 1036,71 \\
\hline 5 minggu (g/ekor/minggu) & $\pm 98,52$ & $\pm 88,89$ & $\pm 140,74$ & $\pm 96,24$ & $\pm 158,08$ \\
\hline \multicolumn{6}{|l|}{ Broiler (0-5 minggu) } \\
\hline Total Konsumsi 0-5 minggu & 3466,75 & 3419,09 & 3428,55 & 3463,08 & 3424,57 \\
\hline (g/ekor) & $\pm 197,05$ & $\pm 177,79$ & $\pm 281,48$ & $\pm 192,48$ & $\pm 316,15$ \\
\hline Rata-rata Konsumsi per minggu 0 & 693,35 & 683,82 & 685,71 & 692,62 & 684,91 \\
\hline 5 minggu (g/ekor/minggu) & $\pm 39,41$ & $\pm 35,56$ & 56,30 & $\pm 38,50$ & $\pm 63,23$ \\
\hline
\end{tabular}

Menurut Anggorodi (1985), salah satu faktor yang mempengaruhi konsumsi ransum adalah palatabilitas. Akan tetapi dikatakan pula bahwa palatabilitas bukanlah hal utama bagi ayam broiler, melainkan kebutuhan energinya. Apabila energinya belum terpenuhi, ayam akan terus makan. Selama periode finisher, ayam broiler membutuhkan konsumsi ransum yang lebih banyak. Kemungkinan, ayam broiler dalam penelitian ini selama periode finisher mengabaikan palatabilitas, namun lebih mengutamakan kebutuhan energinya. Hal ini terlihat dari capaian berat badan akhir ayam broiler yang mendapatkan ransum komersil dengan substitusi tepung kulit pisang kepok fermentasi + bungkil kelapa + feed supplement $\left(\mathrm{P}_{2}-\mathrm{P}_{5}\right)$ tidak jauh berbeda dengan ayam yang mendapatkan sepenuhnya ransum komersil $\left(\mathrm{P}_{1}\right)$.

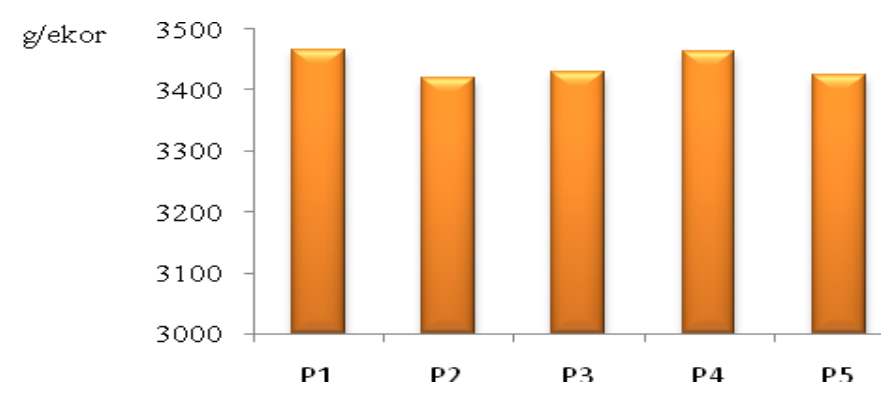

Gambar 3. Total Konsumsi Ransum Ayam Broiler 0-5 minggu dari Semua Perlakuan

\section{Konversi Ransum}

Rataan konversi ransum ayam broiler per minggu yang diberi ransum komersil yang disubstitusi dengan tepung kulit pisang kepok fermentasi + bungkil kelapa + feed supplement selama periode finisher (4-5 minggu) diperlihatkan pada Tabel 4. Hasil sidik ragam memperlihatkan bahwa pemberian ransum komersil yang sebagian disubstistusi dengan tepung kulit pisang kepok fermentasi + bungkil kelapa + feed supplement selama periode finisher (4-5 minggu) tidak berpengaruh nyata $(\mathrm{P}>0,05)$ terhadap rataan konversi ransum ayam broiler. Hal ini dikarenakan tidak ada perbedaan yang nyata pada konsumsi ransum dan pertambahan berat badan ayam dari semua perlakuan. 
Tabel 4. Konversi Ransum Ayam Broiler yang Diberi Ransum Komersil yang

Disubstitusi Tepung Kulit Pisang Kepok Fermentasi + Bungkil Kelapa + Feed Supplement selama Periode Finisher

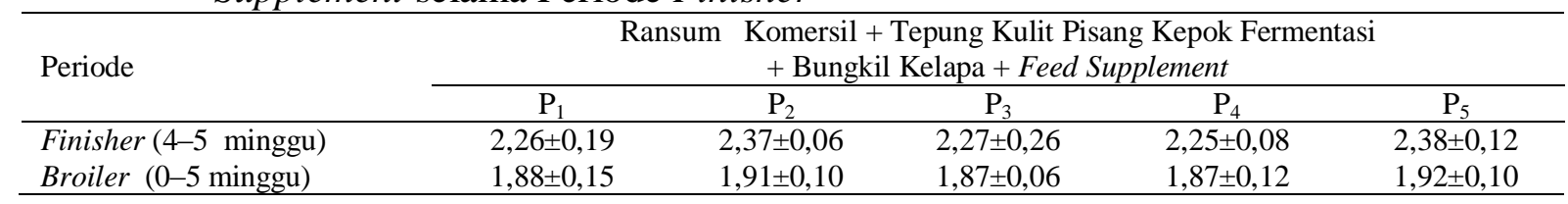

Hasil ini memperlihatkan bahwa meskipun kulit pisang mengandung serat kasar yang tinggi, ayam broiler masih mampu memanfaatkan bahan pakan tersebut dengan catatan (1) bahan difermentasi terlebih dahulu, (2) penggunaannya hanya selama periode finisher, (3) digunakan tidak melebihi 10\%, dan (4) ditambahkan bahan pakan sumber protein, serta (5) ditambahkan $1 \%$ feed supplement. Dengan demikian diharapkan zat-zat makanan dapat tercukupi. Sesuai dengan Nesheim et al. (1979), faktor-faktor yang mempengaruhi konversi pakan antara lain adalah kecukupan zat makanan dalam pakan. Semakin kecil angka konversi ransum, semakin baik ransum tersebut (North dan Bell, 1990).

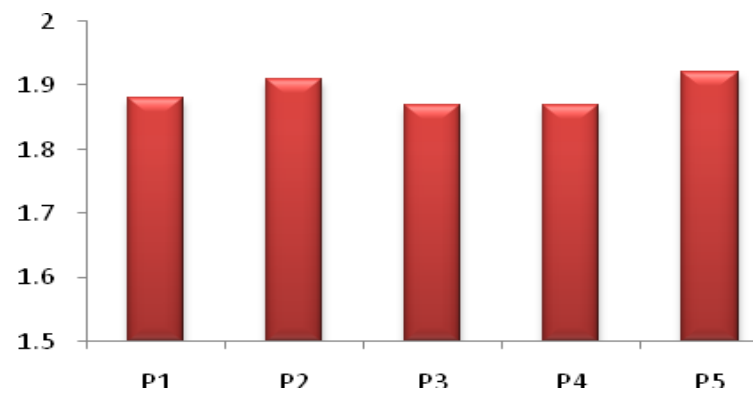

Gambar 6. Rataan Konversi Ransum Ayam Broiler 0-5 minggu dari Semua Perlakuan

\section{KESIMPULAN DAN SARAN}

\section{Kesimpulan}

Tepung kulit pisang kepok fermentasi dapat digunakan sampai $10 \%$ ditambah $6 \%$ bungkil kelapa dan $1 \%$ feed supplement untuk mensubstitusi penggunaan ransum komersil selama periode finisher tanpa berpengaruh nyata terhadap berat badan akhir, pertambahan berat badan, konsumsi, dan konversi ransum ayam broiler.

\section{Saran}

Penggunaan ransum komersil sebaiknya disubstitusi sebanyak-banyaknya $10 \%$ tepung kulit pisang kepok fermentasi $+6 \%$ bungkil kelapa $+1 \%$ feed supplement. Disarankan pula untuk melakukan penelitian lebih lanjut tentang penggunaan tepung kulit pisang fermentasi di dalam ransum unggas.

\section{DAFTAR PUSTAKA}

Anggorodi, R. 1985. Kemajuan Mutakhir dalam Ilmu Makanan Ternak Unggas. PT. Gramedia, Jakarta.

Anggriawan, R., P. Srianto, dan S. H. Warsito. 2013. The benefit of additional banana (Musa paradisiaca L.var sapientum) and mangosteens (Garcinia mangostana L.) skins 
flour toward weight gain and feed conversion in male broiler. Agroveteriner Vol.1, No. 2: $29-36$

Bahri, S. dan Rusdi. 2008. Evaluasi energi metabolis pakan lokal pada ayam petelur.http://jurnal.untad.ac.id/jurnal.index.php/AGROLAND/article/view/ 163/15.

Budiansyah, A. 2010. Performan ayam ayam pedaging yang diberi ransum yang mengandung bungkil kelapa yang difermentasi ragi tape sebagai pengganti sebagian ransum komersial. Jurnal Ilmiah Ilmu-Ilmu Peternakan 13 (50): 260-268.

Hartadi, H., S. Reksohadiprodjo, S. Lebdosukojo, dan A. D. Tillman. 1980. Tabel-tabel dari Komposisi Bahan Makanan Ternak untuk Indonesia (Tables of Feed Composition for Indonesia). The International Feedstuff Institute. Utah Agricultural Experiment Station. Utah State University, Logan, Utah.

Koni, T. N. I. 2009. Pemanfaatan Tepung Kulit Pisang Hasil Fermentasi dengan Jamur Tempe (Rhyzopus oligosporus) dalam Ransum terhadap Pertumbuhan Broiler. Tesis S2 Universitas Nusa Cendana, Kupang.

2012. Pemanfaatan kulit pisang dan ampas kelapa sebagai pengganti jagung dalam ransum terhadap pertumbuhan ayam buras. Buletin Partener 19: 197-203.

2013. Pengaruh pemanfaatan tepung kulit pisang yang difermentasi terhadap karkas broiler JITV 18(2): 153-157.

McDonald, P., R. A. Edwards, and J. F. D. Greenhalgh. 1994. Animal Nutrition. $4^{\text {th }}$ Ed. Longman Scientific and Technical.

Nesheim, M. C., R.E. Austich, and L.E. Card. 1979. Poultry Production. Lea and Febiger, Philadelphia.

North, M. O. and D. D. Bell. 1990. Commercial Chicken Production Manual. $4^{\text {th }}$ Ed. Van Nostrand Reinhold, New York.

Ott, R. L. 1993. An Introduction to Statistical Methodes and Data Analysis. $4^{\text {th }}$ Ed. Duxbury Press. Belmont, California.

Ujianto, A. 2003. Peluang pemanfaatan limbah pisang sebagai pakan ternak. Prosiding Temu Teknis Fungsional Nonpeneliti. Pusat Penelitian dan Pengembangan Peternakan, Bogor.

Udjianto, A., E. Rostiati, dan D.R. Purnama. 2005. Pengaruh pemberian limbah kulit pisang fermentasi terhadap pertumbuhan ayam pedaging dan analisa usaha.

Wahyu, J. 1992. Ilmu Nutrisi Unggas. Cet. ke-3. Gadjah Mada University Press, Yogyakarta.

\section{UCAPAN TERIMAKASIH}

Penulis menyampaikan terima kasih yang sebesar-besarnya kepada Rismanda Sari, Syairazi dan Syafriadi atas kerjasamanya yang baik selama penelitian serta semua pihak yang turut membantu dalam penelitian ini. 